\title{
The impact of cultural values on Vietnamese ethnic entrepreneurs in Germany
}

\section{Quynh Duong Phuong ${ }^{1}$ iD, Aki Harima ${ }^{2}$}

\begin{abstract}
While culture plays a central role in ethnic entrepreneurship, extant research offers a limited understanding of this aspect. This paper investigates the impact of cultural values on Vietnamese ethnic entrepreneurs in Germany. We conducted five case studies with Vietnamese ethnic entrepreneurs. Based on the case studies, we identified four distinct types of cultural values that have a crucial impact on the entrepreneurial activities of the observed Vietnamese entrepreneurs in Germany: i) Family involvement, ii) Cautiousness in entrepreneurial decision-making, iii) Assertiveness in front of the community and iv) Cordiality of service. The study offers an initial insight into the role of cultural values in entrepreneurial decision-making processes of ethnic entrepreneurs and recognizes a reciprocal effect between cultural values and the balance of embeddedness.
\end{abstract}

Keywords: cultural values, ethnic entrepreneurship, ethnic entrepreneurs, embeddedness, Vietnamese ethnic entrepreneurs

\section{INTRODUCTION}

Globalization has reached every corner of the world by now. Advances and cheaper costs in communication and technology have fostered big migration streams as they enable people to maintain distant links more easily (Shuval, 2000; Tung, 2008; Vertovec, 2004). The number of people moving across borders is steadily increasing. In 2015, a global estimate of 244 million international migrants was made, corresponding to $3.3 \%$ of the total world population (International Organization for Migration, 2017). While attempting to gain a foothold in a new country, self-employment is a crucial factor for

1 Quynh Duong Phuong, M.Sc., University of Bremen, Bibliothekstraße 1, 28359 Bremen, Germany, e-mail: phuong@ uni-bremen.de (ORCID ID: 0000-0003-1149-6673)

2 Aki Harima, Ph.D., University of Bremen, Bibliothekstraße 1, 28359 Bremen, Germany, e-mail: harima@uni-bremen. de (ORCID ID: 0000-0001-7499-3488)

Received 30 September 2018; Revised 14 February 2019; Accepted 28 February 2019 
these immigrants' economic advancement (Sanders \& Nee, 1996). As the number of migrants increases, the number of ethnic entrepreneurs also rises continuously. Ethnic communities have started to substitute the migrants' home countries, and particularly the non-significant costs of modern communication technologies have reduced the need for physical proximity to relatives (Gowricharn, 2009). This change in transnationalism significantly promotes ethnic entrepreneurship, which has gained increased attention from researchers over the last years. With increasing globalization, questions about the depth and persistence of cultural differences arise (McGrath, MacMillan, Yang, \& Tsai, 1992). These questions are particularly interesting with regard to migrants who have left their national boundaries and have moved into a society that encompasses cultural value patterns that differ from their own. Thus, being embedded in two different cultural contexts, migrants combine two different cultures in their own ways and create mixed values, which influence how they conduct business as entrepreneurs in their host countries. This dual embeddedness is a particular characteristic of ethnic entrepreneurs. As an integral component of the cultural dimension, value is a central concept to the understanding of human behavior and action (Bilsky \& Schwartz, 1994; Caprara, Schwartz, Capanna, Vecchione, \& Barbaranelli, 2006). It is therefore essential to take a closer look at its impact on the entrepreneurial actions of ethnic entrepreneurs to widen our understanding of this topic. Due to the intangible nature of values, however, the topic is difficult to grasp. Therefore, understanding cultural values requires careful investigation and intense dedication.

Nevertheless, previous research on cultural impact has neglected the role of values in the researchers' observations. While few studies have already tried to detect the impact of cultural values in a general manner without investigating concrete values (Aldrich \& Waldinger, 1990), the studies focusing on particular migrant groups are lacking. It is necessary to investigate the role of cultural values in a particular ethnic group since cultural values are idiosyncratic to ethnic groups and their migration contexts (Pütz, 2003).

Given that each ethnic group holds its own values (Morris \& Schindehutte, 2005) this study will take the first step in addressing this research gap by investigating the values of one particular diaspora group, namely Vietnamese ethnic entrepreneurs in Germany. Since Asian value patterns differ significantly from Western values (Phinney, Ong, \& Madden, 2000), investigating the influence of cultural values on the Vietnamese diaspora is favorable, as it can be observed more clearly. With about 4 million people of Vietnamese heritage living outside of their home country (Ministry of Foreign Affairs of Vietnam, 2012), Vietnam has a "widespread diaspora and a growing rate of entrepreneurship" (Bagwell, 2015). This unique situation of Vietnamese diaspora has attracted 
attention from researchers who have investigated Vietnamese businesses, especially concerning their networks in the UK (Bagwell, 2008, 2015; Hitchcock \& Wesner, 2009). However, in Germany, this diaspora has remained untapped, despite being the largest Asian diaspora group due to its migration history in Germany (Hillmann, 2005), which will be further examined in section three. The Vietnamese diaspora in Germany is most visible through its small businesses, such as restaurants, snack bars and nail salons (Bui, 2003).

This paper aims to provide an insight into the role of cultural values in the entrepreneurial activities of Vietnamese ethnic entrepreneurs, by identifying which cultural values exert influence and how this impact affects the establishment, as well as the management, of the business. Furthermore, a particular focus will be placed on the concept of embeddedness, as it plays a crucial role in the context of ethnic entrepreneurship.

This paper addresses three research questions that build upon each other, which allows for a structured approach to the topic. The research questions are as follows:

1) Which cultural values play significant roles in Vietnamese ethnic entrepreneurship in Germany?

2) How do cultural values influence Vietnamese ethnic entrepreneurs?

3) How do cultural values influence the embeddedness of Vietnamese ethnic entrepreneurs?

The study contributes to the literature on ethnic entrepreneurship by filling the research gap as a result of combining research fields on cultural values and ethnic entrepreneurship through the cases of the Vietnamese diaspora in Germany. The topic is becoming increasingly important, as immigration is growing on a global level. The number of migrant-based businesses is steadily rising. Migrants with a wide variation of motivations and approaches engage in entrepreneurship in their host countries. Against this background, it is essential to explore and understand the concepts and patterns of diaspora businesses. Cultural values play an important role here as they represent subordinate influences from the home country, which are within the entrepreneur and sometimes even contrast with the host country's value patterns. This study can enhance our contextual understanding of migrant entrepreneurship and provide initial insights into what impact cultural values have in entrepreneurial decision-making processes. As a preliminary step towards the investigation of cultural values in migrant entrepreneurship, Germany provides a suitable research location, as it has experienced an immense increase in international migrants in recent years, climbing from 6 th place to 2 nd position among the countries with the highest 
number of migrants between 1990 and 2015 (International Organization for Migration, 2017).

In order to answer the research questions in a structured manner, this paper proceeds as follows. First, a literature review provides the conceptual framework, introducing cultural values and ethnic entrepreneurship and its associated concepts of embeddedness and network theory. Afterward, an overview of the research setting is given. Subsequently, we briefly present the chosen methodological approach and move to our findings, which are compared to the extant literature. Finally, theoretical contributions, practical implications, limitations, and a future outlook are outlined.

\section{LITERATURE BACKGROUND}

\section{Ethnic entrepreneurship and cultural values}

Ethnic entrepreneurship refers to the business activities of migrants that have a common cultural heritage or origin (Volery, 2007). An important characteristic of ethnic entrepreneurs is the access to ethnic resources that comprise "any and all features of their ethnic group that potential owners can use" (Light, 1984, p. 201). Thus, as opposed to native entrepreneurs, the process of the resource mobilization of ethnic entrepreneurs is achieved as a collective community. By using their ethnic, social structures as their organizing capacity, ethnic entrepreneurs draw on their co-ethnic relations for capital and workforce (Aldrich \& Waldinger, 1990). In the ethnic economy, and particularly in ethnic enclaves, networks are essential for the maintenance of business activities since all the resources they use exclusively come from the ethnic network (Zhou, 2006).

This observation leads to the concept of embeddedness that researchers often apply in the field of migrant entrepreneurship (Kloosterman, van der Leun, \& Rath, 1999; Rusinovic, 2008). It helps to understand the diaspora's complex relationship to their environment, and therefore provides an explanation for their entrepreneurial decisions. In 1985, Granovetter first linked the concept of embeddedness to economic behavior and stated that all economic actions are "embedded in concrete, ongoing systems of social relations" (Granovetter, 1985: 487). Embeddedness in a social context can facilitate or constrain entrepreneurship by these links and relations within their networks (Aldrich \& Zimmer, 1986). One crucial point for this study is that embeddedness needs to be understood, not as a fixed state, but as a dynamic process (Ryan \& Mulholland, 2015). 
Researchers have applied this concept to investigation on various aspects of ethnic entrepreneurs, for instance, immigrant enclaves (Portes \& Sensenbrenner, 1993) or diaspora in the apparel industry (Uzzi, 1996). Previous scholars have predominantly focused on the social embeddedness of ethnic entrepreneurs when investigating the ethnic networks as well as their linked access to knowledge and resources (Aldrich \& Waldinger, 1990; Zhou, 2006). The extent of their embeddedness is crucial for the decision to start a business as well as business performance (Schnell \& Sofer, 2002). Korinek, Entwisle and Jampaklay even argued that the "features of social embeddedness are among the most influential factors for migrant settlement, onward movement and return" (Korinek, Entwisle, \& Jampaklay, 2005, p. 794).

Despite extensive research in the field of resources, networks and embeddedness, the cultural component remains rather invisible. Even though culture can have a significant influence on entrepreneurial behavior (Glinka \& Brzozowska, 2015), researchers seem to have taken the role of cultural values for granted, or as naturally given, and have yet not paid particular attention to the impact of cultural values in the context of ethnic entrepreneurship. In some studies, investigators have even treated cultural values as 'attributes' that, in explicit form, have disappeared from the discussion for the most part (Pütz, 2003, p. 555). Cultural values, however, are particularly important for ethnic entrepreneurs as they are a major component of the ethnic resources, which again have a strong impact on the entrepreneurial process (Volery, 2007). Furthermore, research about values linked to entrepreneurship mostly focuses on personal values and has ignored cultural values that, overall, have a strong influence on personal value orientation (Morris, Schindehutte, \& Lesser, 2002). One of the most comprehensive studies about values comes from Hofstede, who defines value as "a broad tendency to prefer certain states of affairs over others" (Hofstede, 2000, p. 5). Another definition characterizes values as 1 ) concepts or beliefs that 2) pertain to desirable end-states or behaviors and 3) transcend specific situations in 4) guiding selection or evaluation of behavior and events, and 5) are ordered by relative importance (Schwartz, 1992, p. 4). Values can be held as an individual but also as a collective community, and are therefore called cultural values. Cultural values represent "the implicitly or explicitly shared abstract ideas about what is good, right, and desirable in a society" (Schwartz, 1999, p. 25) and serve as an orientation for individual values. Furthermore, it is noteworthy that cultural values are not region-bound but "widely held and kept intact though pressure from the unit or group" (Morris \& Schindehutte, 2005, p. 454). This circumstance applies to all ethnic entrepreneurs who reside outside of their home country but are still embedded within their ethnic community on-site. 
The constitution of different cultural value sets can influence the decision to create new businesses, providing a reason for the fact that not all societies or groups are equally eager to engage in entrepreneurship (Bruton, Ahlstrom, \& Li, 2010). Values can also lead to different connotations, nuances, and manifestations in entrepreneurship depending on the cultural region that is looked upon (Morris \& Schindehutte, 2005). Overall, there is a consensus among scholars that the level and nature of entrepreneurial activities vary due to differences in cultural values and beliefs. One possible indication for this assumption is the variance in business foundation rates in different societies (Shapero \& Sokol, 1982) or, in national rates of inventiveness (Shane, 1992). Turro et al. (2014) discovered that the role of culture is crucial for the development of innovation (Turró, Urbano, $\&$ Peris-Ortiz, 2014). Values are learned predispositions, and they have the characteristic of being relatively stable (Schwartz, 2006). Therefore, migrants who come from a different culture often have the values of their country of origin ( $\mathrm{COO}$ ) within their mindset and act accordingly. When residing in a host country, however, there is likely to be an influencing factor coming from the host societies' values. It is therefore especially interesting to investigate how ethnic entrepreneurs orient themselves in a surrounding environment that holds different values than their $\mathrm{COO}$. Values can be the key to understanding why and how ethnic entrepreneurs' behavior, or style of management, differs throughout ethnic groups.

Furthermore, the values can also give an explanation for why specific ethnic groups are more likely to become self-employed than others. However, there has only been limited scholarly attention paid to research addressing explicit values. Against this background, we have decided to investigate one particular ethnic group, which is Vietnamese ethnic entrepreneurs in Germany, whose unique migration history and settings are explained in the following section.

\section{The Vietnamese diaspora in Germany}

The Vietnamese diaspora is the largest Asian diaspora group in Germany (Hillmann, 2005). By the end of 2015, around 87,000 people of Vietnamese nationality lived in Germany. In addition, approximately the same numbers of German citizens with Vietnamese roots live in Germany, so that a total of 176,000 people with a Vietnamese migration background are registered as residents in Germany (Statistisches Bundesamt, 2015). There is also an estimated number of unreported cases of Vietnamese residing in Germany, which leads to a total estimate of about 180,000 people. Being one of the largest diaspora groups in the country, it is therefore of particular relevance 
to investigate this group, as little is known about the Vietnamese diaspora and their entrepreneurial patterns, despite their high visibility in the entrepreneurial landscape in Germany.

The Vietnamese diaspora's bond to their homeland is solid. More than 500,000 Vietnamese who live abroad return to Vietnam annually for investment and family visits (Ministry of Foreign Affairs of Viet Nam, 2012). This homeland orientation is also particularly evident in the flow of remittances. In 2015, Vietnam belonged to the Top 10 countries in terms of remittance recipients (World Bank, 2016) with a total equaling $13.2 \%$ of the country's gross domestic product (International Organization for Migration, 2017).

Contact with Germany is a relatively recent phenomenon (Bui, 2003), starting in 1975 when the immigrant population resettled after the end of the war in Vietnam. Two significant waves of Vietnamese migrants came to Germany, namely the 'contract workers' and the 'boat people.' The socalled boat people were Vietnamese refugees from South Vietnam who fled communism and settled in Western Germany at the beginning of the 1980s after the defeat of the Americans in the Vietnam War. This paper focuses on the first group who migrated due to the severe economic situation in their country at that time. As contract workers came to the German Democratic Republic for temporary work, they were destined to leave the country after a certain period of time. When German reunification took place, many contract workers lost their jobs. Around two-thirds were sent back to Vietnam but found ways to return to Germany in late 1990. They came back to Germany with their family members. After their return, working and living in Germany became more difficult for them due to missing documents. It was not only the legal status of the former contract workers that remained uncertain for a long time but also their documents regarding education and qualifications that were not accepted in Germany, which made it difficult for them to find work. In order to escape the unclear and precarious situation after the reunification, they improvised through self-employment, mostly in the textile trade, food wholesale, retail and flower trade (Schmiz, 2014). The origin of Vietnamese ethnic entrepreneurship in Germany, therefore, had the nature of necessity entrepreneurship (Chrysostome, 2010; Maritz, 2004). Over the past few decades, however, the economic situation and social status of the Vietnamese diaspora in Germany has improved, which enables the modern diaspora to have broader vocational alternatives ranging from employment in the mainstream host-country market to self-employment.

Vietnamese diaspora entrepreneurship in Germany is most visible in the food and service sector (Sutherland, 2007). Particularly noticeable is the rising number of Vietnamese restaurants in big cities such as Hamburg or Berlin. Especially in eastern Berlin, some streets and corners are vastly 
dominated by Asian restaurants with "at least one Vietnamese-run snack bar every five blocks on average" (Bui, 2003, p. 182). According to a study in 2005, Vietnamese entrepreneurs in Germany can be distributed as follows. $45 \%$ of Vietnamese entrepreneurs operate their business in the gastronomy sector. Retail and wholesale account for the second largest share with 35\%, and finally, import and export businesses and other services share third place with 10\% (Dao, 2005 cited in Schmiz, 2014).

\section{METHODOLOGY}

\section{Research design}

This study employs a qualitative and inductive approach in order to capture the motives and reasons behind observable behavior. Qualitative research is suitable to grasp complex and elusive constructs such as values since the research goes beyond measuring observable behavior (Marschan-Piekkari \& Reis, 2004). The inductive reasoning enables this study to follow an unbiased approach to the topic of cultural values, avoiding theoretical preconceptions from existing literature (Hodkinson, 2008).

As current literature has not covered the topic within the targeted diaspora group and lacks emphasis on the concept of embeddedness, this study aims to deliver some initial insight and redefine the possible causalities between cultural values, ethnic entrepreneurial activities, and migrants' embeddedness. The research aim is to build a new theory that is empirically valid, by using multiple case studies and basing itself on the principles of Eisenhardt (1989). Case studies enable the research of a specific phenomenon within their natural settings. The multiple-case study described in this paper consists of five holistic cases, providing a robust base of evidence. Every case represents a first-generation Vietnamese ethnic entrepreneur and his or her business in Germany.

\section{Data selection and data collection}

In order to select suitable cases, we took the following selection criteria into account:

1) When doing case study research with a small number of cases, it is important to "choose cases where the progress is transparently observable" (Pettigrew, 1990, p. 275). As qualitative research focuses on a relatively small number of cases in contrast to quantitative research, purposeful sampling allows the researcher to select information-rich cases 
that allow for an understanding and investigation to the phenomenon in depth (Patton, 2002). Thus, the most important criterion is the openness and willingness of the entrepreneur to talk and share personal stories, as these personal characteristics are essential for the analysis of cultural values, which have a strong intangible nature.

2) Case study participants are first-generation Vietnamese living in Germany and founders of their own companies, following the definition of a Vietnamese ethnic entrepreneur.

3) Their business is located in the predefined regional area, a major city in Lower Saxony. This selection criterion ensures that all entrepreneurs have access to similar institutional structures, which is essential to investigate the embeddedness of the observed entrepreneurs.

For each case, personal interviews with the entrepreneur, their children, as well as employees, serve as a primary source of information. Furthermore, field observation and secondary data through internet research are taken into consideration. We collected primary data via face-to-face interviews in February 2018, using semi-structured interviews. This type of interview represents a fruitful approach with the aim of exploring values, as it allows the interviewer to ask for interpretations of a situation or motives for action in an open form and to raise insights in an open manner (Hopf, 2007). Additionally, the interviewer can freely explore within the predetermined investigation areas (Strauss \& Corbin, 1990).

Furthermore, the face-to-face situation makes it possible for the interviewer to capture subliminal attitudes in addition to the spoken words. The interviews were conducted in Vietnamese and translated into English afterward. The choice of language is especially important when conducting cross-cultural studies, as it affects the dynamics of the interview (MarschanPiekkari \& Reis, 2004). Insufficient language skills on the researcher's or the interviewee's side can lead to misunderstandings or response biases and even missing out on important references in non-verbal communication (Marschan-Piekkari \& Reis, 2004; Ryen, 2003). Holding the conversations in Vietnamese enabled the interviewees to talk more freely, not being hindered by linguistic barriers.

The structured part of the interview covers broad topics revolving around the entrepreneur as well as his or her business, such as their general background story for migration, motives for becoming self-employed, working style, networking, integration of family into business activities, etc. The investigators captured the interviewee's perception of cultural values by particularly scrutinizing the entrepreneur's motives and reasons behind his or her actions. Moreover, their opinion and attitude regarding the motives were questioned. This multiple stage of in-depth questioning allowed for the investigators to 
trace back the origin of the entrepreneur's line of thought, and consequently the moral concept behind it. Investigators paid particular attention to capturing different stages of the venture establishment: a) the planning phase, which describes the time span between taking the decision to found a business and the actual implementation, $b$ ) the establishment phase, the time span in which the entrepreneur founds the business and c) the business execution phase, describing the time span after business opening.

Questions on personal value conceptions have been intentionally omitted since the interviewer should not reproduce preconceived phrases about universally valid values. The aim was only to identify those values that have become visible through the conversation and have found application in the entrepreneurial activities. An overview of the cases is presented in Table 1.

Table 1. Overview of Cases

\begin{tabular}{|c|c|c|c|c|c|c|}
\hline Entrepreneur & Age & $\begin{array}{l}\text { Formal } \\
\text { qualification }\end{array}$ & $\begin{array}{l}\text { Year of } \\
\text { arrival in } \\
\text { Germany }\end{array}$ & $\begin{array}{l}\text { Family } \\
\text { composition in } \\
\text { Germany }\end{array}$ & Venture & $\begin{array}{l}\text { Year of } \\
\text { foundation }\end{array}$ \\
\hline A & 57 & $\begin{array}{l}\text { Apprenticeship in } \\
\text { shipbuilding }\end{array}$ & 1992 & $\begin{array}{l}\text { Wife, two } \\
\text { daughters }\end{array}$ & Restaurant & 2005 \\
\hline B & 51 & $\begin{array}{l}\text { Mechanics for } \\
\text { trains and cars }\end{array}$ & 1991 & $\begin{array}{l}\text { Wife, two } \\
\text { daughters }\end{array}$ & Restaurant & 2005 \\
\hline C & 49 & A-levels & 1987 & $\begin{array}{l}\text { Wife, son, } \\
\text { daughter }\end{array}$ & $\begin{array}{l}\text { Retail } \\
\text { Shop }\end{array}$ & 1999 \\
\hline D & 40 & $\begin{array}{l}\text { Dropped out of } \\
\text { school after } 7 \text { th } \\
\text { grade }\end{array}$ & 2000 & $\begin{array}{l}\text { Husband, } \\
\text { daughter }\end{array}$ & Nail Salon & 2014 \\
\hline$E$ & 52 & $\begin{array}{l}\text { A-levels, studied } \\
\text { Opera for } 2 \text { years }\end{array}$ & 1986 & $\begin{array}{l}\text { Two sons, } \\
\text { daughter, ex- } \\
\text { husband }\end{array}$ & Restaurant & 2016 \\
\hline
\end{tabular}

Since observation enables investigators to capture cultural values from different perspectives (D'Andrade, 2008), one of the authors conducted a field observation in order to experience the daily business and customer interaction in person. This field observation allows for the researcher to get a picture of the business, which adds to an all-embracing view of the company and the situation (Burgess, 2002).

To enhance the quality of the research, we made several efforts in terms of triangulation. Triangulation enhances the accuracy, validity, and reliability of research findings, and thus the level of the study's trustworthiness (Golafshani, 2003). This study collected different types of information such as face-to-face interviews with entrepreneurs and their family members, conversations with employees and entrepreneurs' family members, field observation, and secondary data such as homepage, press articles, and customer reviews. The consideration of multiple data sources enabled us 
to look at the phenomenon from different viewpoints. Furthermore, two researchers participated in data analysis to reduce the negative impact of bias. It is noteworthy that one investigator is a second-generation Vietnamese migrant in Germany who can understand cultural values from an insider's perspective, while the other investigator has no Vietnamese ethnic background, which allows for the person to analyze cultural values from an outsider's viewpoint.

\section{Data analysis}

We analyzed the interviews with regard to the three research questions. A multi-stage coding process took place for the sake of structured data analysis. Due to the inductive and explorative character of the underlying research, the data coding process started without any pre-defined categories. The first step of the analysis is open coding. The idea of open coding is to have many detailed and specific codes by going through transcriptions line by line and paraphrasing the statements in order to gain familiarity with the data. The second step is to do selective coding by identifying possible causal relationships and categorizing them. The coding and categories are thus directly derived from the interviews. Those steps are first done in a within-case analysis. In a further step, the aim is to search for patterns across cases. The continuous iteration between the analysis of initial and selective codes and the extant literature resulted in the development of a preliminary theoretical framework. This step is considered necessary to raise the theoretical level of the findings (Eisenhardt, 1989). The idea is to build a theory from the bottom up, inspired by the coding process of grounded theory (Charmaz, 2014). For the data analysis, we used MAXQDA2018 and Microsoft Excel as technical support.

\section{Vietnamese cultural values and their impact}

Based on the investigated cases, this study identifies four distinctive cultural values that have an impact on entrepreneurial behavior: i) Family involvement; ii) Cautiousness in entrepreneurial planning; iii) Assertiveness in front of the community; and iv) Cordiality of service. This section will introduce each of the identified cultural values while providing empirical evidence, which is then connected to the extant literature.

Table 2 shows an overview of all detected cultural values with their constituent dimension as well as representative quotes. 
Table 2. Overview of values with their constituent dimension

\begin{tabular}{|c|c|c|}
\hline Cultural value & Constituent dimension & Representative quotes \\
\hline \multirow[t]{5}{*}{ Family Involvement } & $\begin{array}{l}\text { Business as a family business } \\
\text { Family members as workforce }\end{array}$ & $\begin{array}{l}\text { "Working as waitresses for a few hours. } \\
\text { Only at times when there were many } \\
\text { customers. Watching the restaurant, } \\
\text { taking phone calls, taking orders, bringing } \\
\text { the food. Basically, being waitresses. "(A) } \\
\text { "It was her who found this place and } \\
\text { the rent is much cheaper. I really like it } \\
\text { because I can save money by renting this } \\
\text { place, so I took it." (D) }\end{array}$ \\
\hline & $\begin{array}{l}\text { Administrative support from } \\
\text { children }\end{array}$ & $\begin{array}{l}\text { "She helps me when I have difficulties, for } \\
\text { example about bureaucratic things and } \\
\text { everything that I'm not familiar with." (D) }\end{array}$ \\
\hline & $\begin{array}{l}\text { Children as the contact person for } \\
\text { business }\end{array}$ & $\begin{array}{l}\text { "When [...] I don't understand it all, then } \\
\text { I have to ask them. Then I just make an } \\
\text { appointment and she will go for me. She } \\
\text { goes to their office, talks to them and then } \\
\text { comes back and explains everything to } \\
\text { me." (A) }\end{array}$ \\
\hline & $\begin{array}{l}\text { Consideration of family member's } \\
\text { opinion }\end{array}$ & $\begin{array}{l}\text { "Another thing is that my eldest son said } \\
\text { that the percentage of Germans who are } \\
\text { vegan or vegetarian is very high. } 27 \% \text {. } \\
\text { So, we need to offer more vegetarian and } \\
\text { vegan dishes." (E) } \\
\text { "For example, when she likes colors that } \\
\text { I don't like, then we both ask each other } \\
\text { and discuss." (D) }\end{array}$ \\
\hline & $\begin{array}{l}\text { Emotional support through } \\
\text { togetherness }\end{array}$ & $\begin{array}{l}\text { "I would always like them to join me in my } \\
\text { work, no matter what kind of work. Just } \\
\text { doing it together." (C) }\end{array}$ \\
\hline \multirow[t]{2}{*}{$\begin{array}{l}\text { Cautiousness in } \\
\text { Entrepreneurial } \\
\text { Decision-making }\end{array}$} & $\begin{array}{l}\text { Experience as a key requirement } \\
\text { for business foundation }\end{array}$ & $\begin{array}{l}\text { "So, I assisted in the kitchen and } \\
\text { slowly, while working there I learned } \\
\text { the profession. I learned and explored } \\
\text { everything and so I got the experience } \\
\text { and the knowledge. That's how you get to } \\
\text { know the profession." (A) } \\
\text { "I think there is nothing difficult in } \\
\text { there because I have gained enough } \\
\text { experience." (B) }\end{array}$ \\
\hline & $\begin{array}{l}\text { Self-assurance in their own skills } \\
\text { before establishing the business }\end{array}$ & $\begin{array}{l}\text { "After I have worked a long time in those } \\
\text { restaurants, I gained much experience. } \\
\text { And through this experience, I am capable } \\
\text { of being a boss on my own. I thought, if } \\
\text { I open a restaurant, I will succeed. Because } \\
\text { I already worked for several restaurants, } \\
\text { German, Chinese and Thai for such a long } \\
\text { period of time, so I was sure I can make } \\
\text { it." (B) }\end{array}$ \\
\hline
\end{tabular}




\begin{tabular}{|c|c|c|}
\hline Cultural value & Constituent dimension & Representative quotes \\
\hline $\begin{array}{l}\text { Cautiousness in } \\
\text { Entrepreneurial } \\
\text { Decision-making }\end{array}$ & \multicolumn{2}{|c|}{$\begin{array}{l}\text { Self-consciousness of own skills and capabilities as well as limits and } \\
\text { boundaries } \\
\text { "It wouldn't be enough. I mean they do have many ideas about this and that, } \\
\text { and I think that is very good, but it lies beyond my capabilities." (C) }\end{array}$} \\
\hline \multirow[t]{2}{*}{$\begin{array}{l}\text { Assertiveness in Front } \\
\text { of the Community }\end{array}$} & Business as own achievement & $\begin{array}{l}\text { Yes, because all my heart is in here. Since } \\
\text { my wife and I opened this restaurant, } \\
13 \text { years have passed already. Generally } \\
\text { speaking, I feel very satisfied with } \\
\text { everything I did and everything that I built } \\
\text { up until now." (B) } \\
\text { "It is just about finding a suitable location } \\
\text { that fits to your own strength. What } \\
\text { I mean is, if the size of the restaurant fits } \\
\text { to your strength, you can make it. [...] If } \\
\text { it fits with your strength and what you } \\
\text { can do, then you won't encounter many } \\
\text { difficulties." (E) }\end{array}$ \\
\hline & Distance to ethnic community & $\begin{array}{l}\text { "No, I never needed any other Vietnamese } \\
\text { to help me except for my own family. It } \\
\text { was either me alone or my children or my } \\
\text { brother. In all of what I have done, I never } \\
\text { needed to rely on any other Vietnamese. } \\
\text { Never." (E) }\end{array}$ \\
\hline \multirow[t]{2}{*}{ Cordiality of Service } & Customer treatment & $\begin{array}{l}\text { "We usually welcome our guests very } \\
\text { heartily. You can see it yourself. The } \\
\text { important thing is that we have this } \\
\text { mentality, that responsibility. That } \\
\text { means that we serve our customers very } \\
\text { thoughtfully." (A) }\end{array}$ \\
\hline & Customer feedback & $\begin{array}{l}\text { "I only do very little advertising, really not } \\
\text { much. But my customers talk with each } \\
\text { other on their own. Just word of mouth." } \\
\text { (B) }\end{array}$ \\
\hline
\end{tabular}

\section{Family involvement}

The first category focuses on the role of the family with Family involvement. Through all cases, we observe that entrepreneurs do not run the business alone, but family members participate in the business in different forms. The entrepreneurs' children help out in the shop as staff or assist in bureaucratic and administrative matters, leveraging their superior language proficiency. In the observed cases, all entrepreneurs let their children act as a second 
contact person for the company. In the case of Entrepreneur D for instance, it was the daughter who managed to find a suitable location for the business.

"It was her who found this place, and the rent is much cheaper. I really like it (the business location) because I can save money by renting this place, so I took it." (Entrepreneur D)

In the case of Entrepreneur $\mathrm{E}$, her son continuously gives suggestions to enhance the quality and variety of the menu by adding new vegetarian and vegan dishes, as the demand for this type of food is rising in Germany. However, the family members are not only valued for their physical support but also for their opinion. Despite being the decision-maker, it is crucial for the entrepreneur to listen to the family's opinion.

"And every time before I ordered the clothes, I usually asked my children as young teens to see if this style fit their age. Or to what age these kinds of clothing would fit. The decision is still mine. But still, I always want to listen to the opinion of my children and my wife." (Entrepreneur C)

The interviewees often emphasize that children are not obligated or forced to help. Still, they do wish and encourage them to work for their business. All interviewees describe their company as a family business, implying that everyone in the family helps and supports the business, regardless of how valuable or useful this support is. The crucial point is that the children should not be indifferent to the business of their parents and also put some thought in it.

"I would always like them to join me in my work, no matter what kind of work. Just doing it together." (Entrepreneur C)

Togetherness and team play in the family regarding the business is the decisive factor that entrepreneurs place much importance on. Through their participation in the business, the family provides the entrepreneur with indispensable emotional support. Receiving support from their spouse and children helps the entrepreneur to sustain emotional stability, which is especially necessary in times of stress and insecurities while founding the business. Sanders and Nee (1996) also emphasize the family as "an institution that embodies an important form of social capital that immigrants draw on in their pursuit of economic advancement" (Sanders \& Nee, 1996: 233). Being such an institution, the main advantages of the family are not only 
the tangible products such as unpaid labor but the intangible ones, involving mutual obligation and trust characteristics (Sanders \& Nee, 1996).

Interestingly, previous research observed this particular attitude toward family members and expectation regarding business engagement in the context of Vietnamese ethnic entrepreneurs in another host country. In a study comparing Vietnamese Americans to non-immigrant U.S. American families, D'Andrade (2008) identified a central characteristic of Vietnamese families that he called the 'family-based achievement syndrome,' which aims at explaining that every achievement is or should be accomplished as a family. During the process of achievement, education, respect and family loyalty are always embedded. The author emphasizes "the family as a central institution through which achievement and knowledge are accomplished" (D'Andrade, 2008: 84). The concept of the 'family-based achievement syndrome' is applicable for the observed cases of Vietnamese ethnic entrepreneurs in Germany, who put considerable emphasis on the fact that family members get involved with and think about the business regardless of the actual benefit for business activities. Their perception of their business as a family business comprises the connotation of a place to live out the "strong and valued family world" (D'Andrade, 2008: 77). The most notable aspect of this value is the new dimension of family involvement to an ethnic business. Previous studies have argued that ethnic and migrant entrepreneurs use family members mainly as staff (Aldrich \& Waldinger, 1990; Volery, 2007). However, the observed entrepreneurs understand their business not only as a business but as a kind of platform where they can develop and foster the solidarity of the family. This new dimension of family involvement implies that the entrepreneurs are not focused on the provided output through family members anymore, but that they place greater importance on team-play as a family, using the ethnic business as its foundation.

\section{Cautiousness in entrepreneurial decision-making}

Dealing with entrepreneurs' behavioral patterns, the second value is Cautiousness in entrepreneurial decision-making. While some started their business without having any vocational experience, the observed entrepreneurs place a great emphasis on gathering experience as a key requirement for becoming entrepreneurs. In four out of five cases, they have already spent several years working in the areas in which they open their business afterward. 
"When you start your business, you always need to have experience first, know the work and should have already worked in a restaurant." (Entrepreneur A)

In the case of Entrepreneur $\mathrm{C}$, he had not gained any experience in the retail industry before. In order to overcome the lack of direct experience, he tried to access as much information as possible and get in touch with several institutions to inform himself before finally deciding on the business. Apart from experience and knowledge, the interviewees are also aware of their abilities and capabilities. This also becomes evident in the case of Entrepreneur B. Even though he has a good command of the German language, as he had already worked as an accountant for a German bakery, he was aware that his German skills at that time were not sufficient to write a business plan in the German language that would be good enough to persuade the bank to give him a loan. Therefore, he needed to ask someone to translate it for him.

Furthermore, the entrepreneurs are especially self-conscious about their boundaries and limits. The way they build and run the business reflects this fact. They only start something when they are sure that it is possible and will not fail. They pay close attention to aligning the business according to their strengths and capabilities. Also, with regard to their competitive behavior, the entrepreneurs think in terms of their capabilities and limits. While being aware of the growing competition, they are very calculative of their abilities and boundaries and are considering their possibilities.

"I would love to offer new things and do some changes. I really love to do new things, but it's only possible within my capabilities and limits." (Entrepreneur E)

Cautiousness has both a positive and negative implication. In the spirit of their cautiousness, the entrepreneurs in the observed cases take their time before founding a company and emphasize the importance of experience and knowledge. The long preparation time allows them to collect a lot of prior knowledge, which plays a vital role in entrepreneurship theory. Literature suggests that prior knowledge about the host and home markets and customers is a source of unique opportunity recognition (Harima et al., 2016). There are three dimensions of prior knowledge that are crucial for opportunity recognition: prior knowledge of markets, prior knowledge of ways to serve markets, and prior knowledge of customer problems (Ardichvili, Cardozo, \& Ray, 2003). The observed entrepreneurs have attempted to build more extensive knowledge in all three dimensions before establishing their business. 
As prospective ethnic entrepreneurs, their opportunities are manageable, which means that the observed entrepreneurs decided to pursue a low-risk and less innovative business opportunity. While engaging in a business sector, they are familiar with; they hold an advantage in the sense that they have broad knowledge, especially about the local market, which enables them to position themselves favorably with their soon-to-be business. For instance, if they intend to start a business in the gastronomy sector, they have room to maneuver in the sense of how they organize their company, whether they open a snack bar or a restaurant, whether it will be a Thai or an Asian restaurant, depending on the current market gap in the targeted geographical sphere. Thus, Cautiousness in entrepreneurial decision-making leads to long preparation time, facilitating rich business know-how and market information, and enabling them to position their venture favorably in the market.

Cautiousness, however, does not only bring advantages when it leads entrepreneurial individuals to be risk-averse. This value contradicts the very nature of entrepreneurs who are credited as being risk-takers (Shane \& Venkataraman, 2000). However, cautiousness often goes along with risk aversion in the sense that entrepreneurs try to keep the risk as low as possible through careful planning. The risk of failure accompanies all kinds of entrepreneurial activities. Taking a wrong decision, the entrepreneur can risk financial well-being, family relations and physical well-being (Brockhaus Sr, 1980). Particularly for an ethnic venture, which is essential for the survival of the family, failure can have substantial consequences. It is due to these circumstances that the entrepreneurs in the case studies care about keeping this risk as low as possible and place great focus on planning and considering all opportunities regarding their feasibility and risks.

Uncertainty also plays a role in this case. According to Lipshitz and Strauss (1997), "uncertainty in the context of action is a sense of doubt that blocks or delays action" (Lipshitz \& Strauss, 1997: 150). Uncertainty becomes particularly problematic when circumstances require immediate action, for instance in the case of competitive threat. Uncertainty then acts as a barrier between the entrepreneur and his or her action, wasting valuable time which could have been invested in counteraction. Since the time frame for capturing opportunities is mostly fleeting (Shane \& Venkataraman, 2000), it is particularly important to be able to act quickly. Conversely, cautiousness restricts the entrepreneur from making quick decisions and it can hinder the entrepreneur from reacting quickly to market changes and, thus, seizing immediate opportunities. 
Assertiveness in front of the community

The third value is Assertiveness in front of the community, in which assertiveness should be understood as the entrepreneurs' self-assertion towards their ethnic community. What was observable in the case studies is the overall reluctance of interviewees to make use of the Vietnamese community for their business.

"No, I never needed any other Vietnamese to help me except for my own family. It was either me alone or my children or my brother. In all of what I have done, I never needed to rely on any other Vietnamese. Never!" (Entrepreneur E)

When it comes to supporting, the interviewed entrepreneurs draw a clear line between their family and the ethnic community. Although they like to meet the community for socializing, they tend to avoid asking acquaintances or people with whom they are not close friends for support. The analysis reveals two reasons for this reluctant attitude. The establishment of a business is a personal matter; therefore, they do not need any external help, meaning everyone who is not included in the circle of strong ties. The personal touch is also reflected in the fact that they see their business as a life achievement, something they have created with their strength. That is also the way they communicate it.

The entrepreneurs also revealed the reason why external support is so reprehensible. In their eyes and that of the community, the business is regarded as more valuable if one accomplishes it on one's own and does not have to ask others for help. Moreover, when asking someone for help in the Vietnamese community, this information spreads quickly, which leads to the creation of a reputation for being 'weak' and dependent on support. In fact, saving face is a crucial aspect in Asian cultures, as the face represents an individual's image, which is partly dependent on the evaluation of society (Thanh, 2010; Thi \& Nhung, 2014). Interestingly, the empirical data shows that entrepreneurs' concern about their reputation in the community is only related to the Vietnamese ethnic community. Reputation in the German community does not seem to play a significant role in this aspect. Vietnamese entrepreneurs only compare themselves to other Vietnamese diaspora.

In the case of this specific value, both their pride and the position of the community ties play an important role. Entrepreneurs and also nascent entrepreneurs take pride in their business as their achievement. This attitude is also held by entrepreneurs when facing their ethnic community. In order 
to prove themselves to the community, they do not seek any help from the community during the founding process. This attitude leads to a self-made disadvantage since they decide not to draw on their ethnic resources in this particular stage of venture establishment anymore. By relying only on their strong ties, they deny advantages of weak ties and the use of ethnic resources that can have a major impact in facilitating business start-ups (Sanders \& Nee, 1996). These findings contradict prevailing assumptions about ethnic entrepreneurs regarding their reliance on ethnic, social capital (Aldrich \& Waldinger, 1990; Aldrich \& Zimmer, 1986; Mayer, Harima, \& Freiling, 2015; Volery, 2007). Zimmer and Aldrich (1987) suggest that Asian business owners are likely to reach out to their ethnic kinship for funds and staff.

Interestingly, this is not the case with any of our observed entrepreneurs, who reject considering their ethnic community for assistance. By narrowing their network during the venture establishment stage, they fail to leverage resources and thus, ethnic advantages for the business coming from the Vietnamese ethnic community. This imbalance of embeddedness is, however, intentional as they purposely keep a distance from the community during their establishment stage.

\section{Cordiality of service}

The last value concerns the interaction with customers and is called Cordiality of service. In the case studies, field observation showed that customer relations are of particular significance. Regardless of whether they are in a bad mood or under stress, as soon as the entrepreneur talks to customers, he or she entirely concentrates on the customer and welcomes him with cordiality. The statement of Entrepreneur B also supports this value, who confirms that the treatment of customers is paramount. A good customer relationship is worth more than the immediate profit.

"You need to know how to make customers want to come back to you, once they visit you. It is not only about taking the money from them once. There are many times you have to suffer losses, but you still have to do everything, so they do not leave a bad word about you. That is the first point. Secondly, when they come to you, you need to create something in their hearts that makes them feel assured and leave a feeling of sympathy, which makes them want to come back to you. This is what makes it difficult for a restaurant to go well." (Entrepreneur B)

Regarding the treatment of customers, the most striking aspect is the cordiality with which they welcome their customers. All entrepreneurs set their priority as their customers' satisfaction. They do not take on a formal 
role as in Japanese culture (Winsted, 1997), but they try to create a welcoming and hearty atmosphere and take on the role of a friend rather than a server.

The service culture is firmly rooted in the Asia-Pacific Region (Schmitt \& Pan, 1994). The concept of service has been institutionalized in everyday life of Asians and can be found for instance in the "rituals surrounding the serving and drinking of tea, in host-guest relations, and packaging rituals" (Schmitt \& Pan, 1994, p. 45). In contrast to Western culture, where efficiency and saving time are more valued, Asian culture appreciates a person-oriented service with high personal attention (Mattila, 2000; Schmitt \& Pan, 1994).

By this means, they maintain good interactions with customers, which is crucial for building successful relationships (Chase \& Tansik, 1983). Due to the amicable tie that they were able to establish with their customers, the relationship even goes beyond the ordinary employee-customer relationship. Their Cordiality of service fosters not only customer satisfaction and consequently customer retention, but also leads the customers to engage in supporting the entrepreneurs actively.

"They come here to eat regularly, and they really like my restaurant and me, so they also give me advice. For example, they tell me that I should do more marketing, or I should do this or that. There are a lot of nice customers who help me. If I encounter difficulties, they voluntarily help me." (Entrepreneur E)

All these observations show that the entrepreneurs place great importance on building a close and cordial relationship with their customers, which again leads to customers expressing their goodwill towards the entrepreneurs through active support in different ways.

\section{Impact on embeddedness}

The findings suggest that the identified cultural values significantly influence the social interactions of ethnic entrepreneurs. Thus, in light of our third research question, we further investigated the impact of these cultural values on the entrepreneurs' embeddedness. This research project identified five types of networks with which the entrepreneurs maintain regular contact: family, ethnic community, customers, business network and lastly, public and institutional authorities. The following patterns could be observed:

1) Starting with their decision to found a business, the nascent Vietnamese entrepreneurs in the observed cases utilized all their available networks to gain as much knowledge, information, and experience as possible. They particularly used their network at their current work, as well as their ethnic network for this purpose. Furthermore, they got in contact with as many different people as possible to gather information, especially regarding the experience of already established entrepreneurs. 
2) During the stage of venture establishment, they only relied on the country of residence's (COR) institutions and their strong ties. In this stage, they kept their interactions with the ethnic community to a minimum. This behavior is due to their Assertiveness in front of the community as outlined earlier. Missing information or knowledge during the entrepreneurial process is drawn from the public agencies of the COR, which are responsible for the registration of businesses. The observed entrepreneurs did not feel uncomfortable asking these agencies for assistance, as they do not belong to the ethnic community but are the first point of contact for business foundation.

3) After the business foundation is completed, the respective entrepreneurs maintain a good relationship with the actors in their business network as casual business relations for obtaining news and for keeping in touch with the business scene. Once the business is running, the most important network is their customer base. The customers provide the entrepreneurs with essential information about trends; they give advice on developing the business and share their valuable experience. As for the shop owner (Entrepreneur C), his business network represents the most critical network as other entrepreneurs provide him with useful information. The role of the ethnic community stays relatively unimportant as the observed entrepreneurs stay in touch only because of kinship ties, but do not concern the community with any business matters. Another striking observation is that the interviewees do not draw on ethnic suppliers but rather choose to accept the offer of German wholesalers. By doing so, they intentionally sever the connection to the ethnic community on their supply side, which again minimizes their dependency on the ethnic community.

These findings are unique in so far that they contradict the prevailing literature on ethnic entrepreneurship. Scholars have widely suggested that the ethnic network plays a significant role in immigrant entrepreneurship (Brüderl \& Preisendörfer, 1998). Ethnic entrepreneurs usually draw on their community for resources in the form of money, staff, and information as they are easier to obtain within the network than from outside of their ethnic community (Aldrich \& Waldinger, 1990). Conversely, we could observe a nearly opposite attitude towards the ethnic network in the case of our interviewees. They do not prioritize the ethnic network regarding business support.

On the contrary, they even tried to avoid involving the members of the ethnic community with their business as much as possible. Previous scholars already discovered that the Vietnamese diaspora is characterized by a high level of involvement in the ethnic community (Zhou \& Bankston III, 1994). Members of the community are strongly linked to each other and are always aware of everything that happens within the community. Members of the community are well-observed, since "the community is watchful and ever- 
vigilant" (Nash, 1992 in Zhou \& Bankston III, 1994, p. 831). Due to this fact, the Vietnamese entrepreneurs are not able to move freely within the community, since all actions are "constantly judged and observed by others under a 'Vietnamese microscope'" (Nash, 1992 in Zhou \& Bankston III, 1994). Under these circumstances, as soon as the entrepreneurs ask for help from other community members, the entire ethnic community is aware of it, which again sheds a bad light on the entrepreneurs.

This observed phenomenon can be linked to the concepts of under- and over-embeddedness, where the level of embeddedness is not well-balanced and might even lead to hindrances for business activities (Schnell \& Sofer, 2002). Over-embeddedness characterizes firms that are highly embedded in their local community and operate under the influence of kinship structures so that the resulting commitment impedes them from participating in new or inter-ethnic markets. As the above investigated Arab entrepreneurs received the intensive support of their family and ethnic community; they felt obliged and indebted to their relatives. This particular feeling again hindered them from taking their chances of changing their business location and expanding their business (Schnell \& Sofer, 2002). The interviewees tried to avoid these obligations and potential obstacles of being over-embedded in their ethnic community by keeping them out of their business as far as possible. They only activate the ethnic network for gathering information in the planning phase and they make use of support from institutional authorities rather than an ethnic network for business matters.

This observation offers a novel insight: that it is essential to consider the time dimension during the course of business development when investigating the embeddedness of ethnic entrepreneurs. Embeddedness and, consequently, social capital "should thus be treated as 'a process,' rather than a concrete object that facilitates access to the benefits and resources (Fernández-Kelly, 1995 cited in Zhou \& Bankston III, 1994) that best suit to the goals of specific immigrant groups" (Zhou \& Bankston III, 1994, p. 825). Due to their value priorities, the entrepreneurs actively influence this process by extending and minimizing their interactions with specific networks during the whole entrepreneurial process, starting from the time when they decided to become self-employed. In all cases, it becomes visible that they have actively regulated their embeddedness by drawing upon different networks at different stages of their venture. By doing so, they try to dodge ethnic obligations, but at the same time accept a loss of potential resource. Overall, the observed entrepreneurs try to rely on the ethnic community as little as possible. Instead, they seek to either make it on their own with their family or to get support from COR institutions and business networks. Barrett et al. (2002), who investigated immigrant enterprises in Britain, also argued that 
there could be a "relocation from ethnic to external mainstream resources" (Barrett, Jones, McEvoy, \& McGoldrick, 2002, p. 25), which indicates shifting embeddedness. Given these points, the explicit cultural values, which arose from the diaspora situation of the entrepreneurs, were one of the main reasons for the phenomenon of the entrepreneurs' shifting embeddedness.

\section{DISCUSSION AND CONCLUSION}

\section{Research contributions and practical implications}

This study contributes to the current state of research in a threefold manner. First, it identifies four distinctive cultural values that have a diverse impact on Vietnamese ethnic entrepreneurs: Family involvement, Cautiousness in entrepreneurial decision-making, Assertiveness in front of the community and Cordiality of service. These values become visible in interactions with different groups of people: family, the ethnic community and customers.

Literature has already shown that family and the ethnic community are crucial networks for diaspora entrepreneurs (Aldrich \& Waldinger, 1990; Chaganti \& Greene, 2002). However, this study revealed that the ethnic community is not necessarily the most important type of network for ethnic entrepreneurs. Vietnamese ethnic entrepreneurs in our case studies value the network with customers as the most important information source for their business. In other words, this study sheds light on the role of customers as a unique source for the social capital of ethnic entrepreneurs. This finding calls for the necessity to have a more holistic view of their embeddedness by including the group of customers to their overall network. This opens a new possible stream of research, expanding the present field of research concerning the embeddedness of ethnic entrepreneurs. In order to investigate other cultural values in the context of ethnic entrepreneurship, it would be beneficial to have a closer look at the three most important stakeholder dimensions that have been detected in this study.

Secondly, the findings of this paper extend the literature on ethnic entrepreneurship by investigating unique relationships between cultural values and entrepreneurial activities. The case studies revealed, for instance, a tricky relationship between cultural values and family business involvement, in that, Vietnamese entrepreneurs value collaborative activities as a family, and therefore encourage their family members to contribute to their business. The fact that family members are somehow involved in business is more important than the effect of their support on their business. These findings 
open a new discussion regarding family involvement in ethnic business, as the previous literature predominantly looked at family involvement as a cost reduction mechanism for ethnic entrepreneurs (Aldrich \& Waldinger, 1990). Another counterintuitive finding is the impact of their cultural values on their embeddedness and usage of network resources. We observed the behavior of ethnic entrepreneurs who avoid using ethnic capital due to their community values. This finding added a novel aspect to academic discussions over how and when ethnic entrepreneurs use their ethnic capital (Brüderl \& Preisendörfer, 1998; Chaganti, \& Greene, 2002).

Thirdly, this paper makes a conceptual bridge between embeddedness and cultural values. While the previous literature has not explicitly connected these concepts, our research shows that cultural values influence the behavior and decisions of ethnic entrepreneurs, which affects the balance of dual embeddedness in host-country and ethnic institutions. This finding extends the current understanding of embeddedness in the context of ethnic entrepreneurs by shedding light on the impact of entrepreneurs' cultural values.

\section{Limitations}

Despite the various contributions, this study has some limitations. Due to the intangible nature of values, investigation of this topic requires researchers to have a sharp observation and critical reflection skills, as they need to rely on the statements of the entrepreneurs as well as their own observations. We encountered some obstacles during this investigation, as the interviewees were sometimes hesitant to talk openly about the ethnic community while having the interview recorded. However, they were willing to talk freely after the recording stopped. Another challenge is the differentiation between cultural values and personal values since the boundaries are often blurred. Due to time restrictions, the number of case studies used in the study was limited to five. It is therefore recommended to do the research with an even greater number of samples, including different industry sectors and knowledgeintensive ventures at best, in order to cover a wider entrepreneurial sample group. A larger sample could also ensure the quality and validity of criteria regarding the identified values and their impact.

\section{Future outlook}

As every diaspora is unique in its own way (Khayati Dahlstedt, 2015; Werbner, 2002), it is especially interesting to investigate entrepreneurs of other diaspora groups regarding their cultural value patterns. It might be interesting to compare the value concepts of different diaspora groups, for instance, other 
major immigrant communities in Germany, and derive practical implications for entrepreneurial issues. To enable easier comparison, it is reasonable to develop an analytical framework beforehand that can be adapted to different diaspora groups in a flexible way.

It is also notable that "immigrant cultural orientations are not only rooted in the social structure of the immigrant community but are also responsive to the social environment surrounding the community" (Zhou \& Bankston III, 1994: 841). The statement implies that cultural values are not entirely persistent, but that they do respond to the society of the country of residence. This assumption needs further investigation with a greater number of samples as well as observations over a longer period of time.

\section{References}

Aldrich, H. E., \& Waldinger, R. (1990). Ethnicity and entrepreneurship. Annual Review of Sociology, 16(1), 111-135. https://doi.org/10.1146/annurev. so.16.080190.000551

Aldrich, H., \& Zimmer, C. (1986). Entrepreneurship through social networks. California Management Review. https://doi.org/10.2139/ssrn.1497761

Ardichvili, A., Cardozo, R., \& Ray, S. (2003). A theory of entrepreneurial opportunity identification and development. Journal of Business Venturing, 18(1), 105-123.

Bagwell, S. (2008). Transnational family networks and ethnic minority business development The case of Vietnamese nail-shops in the UK. International Journal of Entrepreneurial Behavior \& Research, 14(6), 377-394. https:// doi.org/10.1108/13552550810910960

Bagwell, S. (2015). Transnational entrepreneurship amongst Vietnamese businesses in London transnational entrepreneurship amongst Vietnamese businesses in London.Journal of Ethnic and Migration Studies, 41(2), 329-349. https://doi.org/10.1080/1369183X.2014.907739

Barrett, G., Jones, T., McEvoy, D., \& Mcgoldrick, C. (2002). The economic embeddedness of immigrant enterprise in Britain. International Journal of Entrepreneurial Behaviour \& Research, 8(1/2), 11-31. https://doi. org/10.1108/13552550210423697

Bilsky, W., \& Schwartz, S. H. (1994). Values and personality. European Journal of Personality, 8(3), 163-181. https://doi.org/10.1002/per.2410080303

Brockhaus Sr, R. H. (1980). Risk taking propensity of entrepreneurs. Academy of Management Journal, 23(3), 509-520.

Brüderl, J., Preisendörfer, P. (1998). Network support and the success of newly founded businesses. Small Business Economics, 10(3), 213-225.

Bruton, G.D., Ahlstrom, D., \& Li, H.L. (2010). Institutional theory and entrepreneurship: Where are we now and where do we need to move in the future? Entrepreneurship: Theory and Practice, 34(3), 421-440. https://doi.org/10.1111/j.1540-6520.2010.00390.x 
Bui, P. (2003). Envisioning Vietnamese Migrants in Germany: Ethnic Stigma, Immigrant Origin Narratives and Partial Masking. Germany: LIT Verlag Münster.

Burgess, R. G. (2002). In the Field: An Introduction to Field Research. London, UK: Routledge.

Caprara, G. V., Schwartz, S., Capanna, C., Vecchione, M., \& Barbaranelli, C. (2006). Personality and politics: Values, traits, and political choice. Political Psychology, 7(1), 1-28. https://doi.org/10.1111/j.14679221.2006.00447.x

Chaganti, R., \& Greene, P. G. (2002). Who are ethnic entrepreneurs? A study of entrepreneursapos: Ethnic involvement and business characteristics. Journal of Small Business Management, 40(2), 126-143. https://doi. org/10.1111/1540-627X.00045

Charmaz, K. (2014). Constructing Grounded Theory. Los Angeles: Sage.

Chase, R. B., \& Tansik, D. A. (1983). The customer contact model for organization design. Management Science, 29(9), 1037-1050.

Chrysostome, E. (2010). The success factors of necessity immigrant entrepreneurs : In search of a model. Thunderbird International Business Review, 52(2), 137-152. https://doi.org/10.1002/tie

D'Andrade, R. (2008). A Study of Personal and Cultural Values: American, Japanese, and Vietnamese. Germany: Springer.

Eisenhardt, K. M. (1989). Building theories from case study research. Academy of Management Review, 14(4), 532-550. https://doi.org/10.5465/ AMR.1989.4308385

Glinka, B., \& Brzozowska, A. (2015). Immigrant entrepreneurs: In search of identity. Entrepreneurial Business and Economics Review, 3(3), 51-76. https://doi.org/10.15678/EBER.2015.030304

Golafshani, N. (2003). Understanding reliability and validity in qualitative research. The Qualitative Report, 8(4), 597-606.

Gowricharn, R. (2009). Changing forms of transnationalism. Ethnic and Racial Studies,32(9),1619-1638. https://doi.org/10.1080/01419870902853232

Granovetter, M. (1985). Economic action and social structure: The problem of embeddedness. American Journal of Sociology, 91(3), 481-510. https:// doi.org/10.1086/228311

Harima, A.; Elo, M. ; Freiling, J. (2016). Rich-to-poor diaspora ventures: How do they survive? International Journal of Entrepreneurship and Small Business, 28(4), 391-413.

Hillmann, F. (2005). Riders on the storm: Vietnamese in Germany's two migration systems. In E. Spaan, F. Hillmann, \& T. van Naerssen (Eds.), Asian Migrants and European Labour Markets: Patterns and Processes of Immigrant Labour Market Insertion in Europe (pp. 80-100). London, UK: Routledge. https://doi.org/10.4324/9780203016053

Hitchcock, M., \& Wesner, S. (2009). Vietnamese values, networks and family businesses in London. Asia Pacific Business Review, 15(2), 265-282. https://doi.org/10.1080/10438590701719032 
Hodkinson, P. (2008). Grounded theory and inductive research. In G.Nigel (Ed.), Researching Social Life (pp. 81-100). London: Sage.

Hofstede, G. H. (2001). Culture's Consequences: Comparing Values, Behaviours, Institutions, and Organizations Across Nations. London: Sage.

Hopf, C. (2007). Qualitative interviews - ein Überblick. In F. Uwe von Kardoff \& E.S. Ines (Eds.), Qualitative Forschung. Ein Handbuch. (pp. 349-360). Hamburg: Qualitative Forschung Ein Handbuch.

International Organization for Migration (2017). Vietnam Migration Profile 2016 released. Retrieved from http://tgvn.com.vn/vietnam-migrationprofile-2016-released-55464.html

Khayati, K., \& Dahlstedt, M. (2015). Diaspora: Relations and communities across borders. In M. Dahlstedt \& A. Neergaard (Eds.), International Migration and Ethnic Relations (pp. 80-103). London, UK: Routledge.

Kloosterman, R., van der Leun, J. P., \& Rath, J. (1999). Mixed embeddedness, migrant entrepreneurship and informal economic activities. International Journal of Urban and Regional Research, 23(2), 253-267. https://doi. org/10.1111/1468-2427.00194

Korinek, K., Entwisle, B., \& Jampaklay, A. (2005). Through thick and thin: Layers of social ties and urban settlement among Thai migrants. American Sociological Review, 70(5), 779-800. https://doi. org/10.1177/000312240507000503

Light, I. (1984). Immigrant and ethnic enterprise in North America. Ethnic and Racial Studies, 7(2), 195-216. https://doi.org/10.1080/01419870.1984.9 993441

Lipshitz, R., \& Strauss, O. (1997). Coping with uncertainty: A naturalistic decision-making analysis. Organizational Behavior and Human Decision Processes, 69(2), 149-163.

Maritz, A. (2004). New Zealand necessity entrepreneurs. International Journal of Entrepreneurship and Small Business, 1(3-4), 255-264. https://doi. org/10.1504/IJESB.2004.005655

Marschan-Piekkari, R., \& Reis, C. (2004). Language and languages in cross-cultural interviewing. In R. Marschan-Piekkari \& C. Welch (Eds.), Handbook of Qualitative Research Methods for International Business, (pp. 224-243). Cheltenham: Edward Elgar. https://doi. org/10.4337/9781781954331.00027

Mattila, A. S. (2000). The impact of culture and gender on customer evaluations of service encounters. Journal of Hospitality \& Tourism Research, 24(2), 263-273.

Mayer, S. D., Harima, A., \& Freiling, J. (2015). Network benefits for Ghanaian diaspora and returnee entrepreneurs. Entrepreneurial Business and Economics Review, 3(3), 95-121. https://doi.org/10.15678/ EBER.2015.030306

McGrath, R. G., MacMillan, I.C., Yang, E.A.Y., \& Tsai, W. (1992). Does culture endure, or is it malleable? Issues for entrepreneurial economic 
development. Journal of Business Venturing, 7(6), 441-458. https://doi. org/10.1016/0883-9026(92)90019-N

Ministry of Foreign Affairs of Viet Nam, (2012). Review of Vietnamese Migration Abroad. Retrieved from http://www.un.org.vn/en/publications/doc_ details/387-review-of-vietnamese-migration-abroad.html

Morris, M., \& Schindehutte, M. (2005). Entrepreneurial values and the ethnic enterprise: An examination of six subcultures. Journal of Small Business Management, 43(4), 453-479. https://doi.org/10.1111/j.1540627X.2005.00147.x

Morris, M., Schindehutte, M., \& Lesser, J. (2002). Ethnic entrepreneurship: Do values matter? New England Journal of Entrepreneurship, 5(2), 35-46.

Patton, M. Q. (2002). Qualitative Research and Evaluation Methods. California: Sage Publications Inc.

Pettigrew, A. M. (1990). Longitudinal field research on change: Theory and practice. Organization Science, 1(3), 267-292. https://doi.org/10.1287/ orsc.1.3.267

Phinney, J. S., Ong, A., \& Madden, T. (2000). Cultural values and intergenerational value discrepancies in immigrant and non-immigrant families. Child Development, 71(2), 528-539.

Portes, A., \& Sensenbrenner, J. (1993). Embeddedness and immigration: Notes on the social determinants of economic action. American Journal of Sociology, 98(6), 1320-1350. https://doi.org/10.1086/230191

Pütz, R. (2003). Culture and entrepreneurship - Remarks on transculturality as practice. Tijdschrift Voor Economische En Sociale Geografie, 94(5), 554-563. https://doi.org/10.1046/j.1467-9663.2003.00282.x

Rusinovic, K. (2008). Transnational embeddedness: Transnational activities and networks among first- and second-generation immigrant entrepreneurs in the Netherlands. Journal of Ethnic and Migration Studies, 34(3), 431451. https://doi.org/10.1080/13691830701880285

Ryan, L., \& Mulholland, J. (2015). Embedding in motion: Analysing relational, spatial and temporal dynamics among highly skilled migrants. In L. Ryan, U. Erel, \& A. D’Angelo (Eds.), Migrant Capital. Networks, Identities and Strategies (pp. 135-153). Germany: Springer.

Ryen, A. (2003). Cross-cultural interviewing. In J.A. Holstein \& J.F. Gubrium (Eds.), Inside Interviewing: New Lenses, New Concerns (pp. 429-448). London: Sage.

Sanders, J. M., \& Nee, V. (1996). Immigrant self-employment: The family as social capital and the value of human capital. American Sociological Review, 61(2), 231-249.

Schmitt, B. H., \& Pan, Y. (1994). Managing corporate and brand identities in the Asia-Pacific region. California Management Review, 36(4), 32-48. https://doi.org/10.2307/41165765

Schmiz, A. (2014). Transnationalität als ressource? Netzwerke vietnamesischer Migrantinnen und Migranten zwischen Berlin und Vietnam. Germiny: transcript Verlag. 
Schnell, I., \& Sofer, M. (2002). Unbalanced embeddedness of ethnic entrepreneurship: The Israeli Arab case. International Journal of Entrepreneurial Behaviour \& Research, 8(1-2), 54-68. https://doi. org/10.1108/13552550210423714

Schwartz, S. H. (1992). Universals in the content and structure of values: Theoretical advances and empirical tests in 20 countries. Advances in Experimental Social Psychology, 25, 1-65. https://doi.org/10.1016/ S0065-2601(08)60281-6

Schwartz, S. H. (1999). A theory of cultural values and some implications for work. Applied Psychology, 48(1), 23-47. https://doi. org/10.1080/026999499377655

Schwartz, S. H. (2006). A theory of cultural value orientations: Explication and applications. Comparative Sociology, 5(2), 137-182. https://doi. org $/ 10.1163 / 156913306778667357$

Shane, S. A. (1992). Why do some societies invent more than others? Journal of Business Venturing, 7(1), 29-46. https://doi.org/10.1016/08839026(92)90033-N

Shane, S., \& Venkataraman, S. (2000). The promise of entrepreneurship as a field of research. Academy of Management Review, 25(1), 217-226.

Shapero, A., \& Sokol, L. (1982). Social dimensions of entrepreneurship. In C. Kent, D. Sexton, \& K. Vesper (Eds.), The Encyclopedia Of Entrepreneurship (pp. 72-90). Englewood Cliffs, NY: Prentice Hall. https://doi.org/10.1093/ oxfordhb/9780199546992.003.0019

Shuval, J. T. (2000). Diaspora migration: definitional ambiguities and a theoretical paradigm. International Migration, 38(5), 41-56. https:// doi.org/10.1111/1468-2435.00127

Statistisches Bundesamt. (2015). Statistisches Bundesamt Bevölkerung und Erwerbstätigkeit - Bevölkerung mit Migrationshintergrund. Destatis. Retrieved from https://www-genesis.destatis.de/genesis/online

Strauss, A., \& Corbin, J. (1990). Basics of qualitative research: Grounded theory procedure and techniques. Qualitative Sociology, 13(1), 3-21.

Sutherland, C. (2007). Digesting Diasporas: Vietnamese Migrants and German Multiculturalism. Cambridge: Cambridge Scholars Publishing.

Thanh, P. T. H. (2010). Implementing a student-centered learning approach at Vietnamese higher education institutions: Barriers under layers of Casual Layered Analysis (CLA). Journal of Futures Studies, 15(1), 21-38.

Thi, P., \& Nhung, H. (2014). How do the Vietnamese lose face ? Understanding the concept of face through self-reported, face loss incidents. International Journal of Language and Linguistics, 2(3), 223-231. https:// doi.org/10.11648/j.ijll.20140203.21

Tung, R. L. (2008). Brain circulation, diaspora, and international competitiveness. European Management Journal, 26(5), 298-304. https://doi.org/10.1016/j.emj.2008.03.005

Turró, A., Urbano, D., \& Peris-Ortiz, M. (2014). Culture and innovation: The moderating effect of cultural values on corporate entrepreneurship. 
Technological Forecasting and Social Change, 88, 360-369. https://doi. org/10.1016/j.techfore.2013.10.004

Uzzi, B. (1996). The sources and consequences of embeddedness for the economic performance of organizations: The network effect. American Sociological Review, 61(4), 674-698. https://doi.org/10.2307/2096399

Vertovec, S. (2004). Migrant transnationalism and modes of transformation. International Migration Review, 38(3), 970-1001.

Volery, T. (2007). Ethnic entrepreneurship: A theoretical framework. In L-P. Dana (Ed.), Handbook Of Research On Ethnic Minority Entrepreneurship: A Co-evolutionary View on Resource Management (pp. 30-41). UK: Edward Elgar Publishing. https://doi.org/10.1016/S1074-7877(03)04012-1

Werbner, P. (2002). The place which is diaspora: Citizenship, religion and gender in the making of chaordic transnationalism. Journal of Ethnic and Migration Studies, 28(1), 119-133.

Winsted, K. F. (1997). The service experience in two cultures: A behavioral perspective. Journal of Retailing, 73(3), 337-360.

World Bank. (2016). Migration and Remittances: Factbook 2016. Library. Retrieved from https://doi.org/10.1080/17441730.2013.785721

Zhou, M. (2006). Revisiting ethnic entrepreneurship: Convergencies, controversies, and conceptual advancements. International Migration Review, 38(3), 1040-1074. https://doi.org/10.1111/j.1747-7379.2004. tb00228.x

Zhou, M., \& Bankston III, C. L. (1994). Social capital and the adaptation of the second generation: The case of Vietnamese youth in New Orleans. International Migration Review, 28(4), 821-845.

Zimmer, C., \& Aldrich, H. (1987). Resource mobilization through ethnic networks: Kinship and friendship ties of shopkeepers in England. Sociological Perspectives, 30(4), 422-445.

\begin{abstract}
Abstrakt
Podczas gdy kultura odgrywa kluczowa rolę w przedsiębiorczości etnicznej, istniejqce badania oferujq ograniczone zrozumienie tego aspektu. Niniejszy artykuł bada wpływ wartości kulturowych na wietnamskich przedsiębiorców etnicznych w Niemczech. Przeprowadziliśmy pięć studiów przypadku z wietnamskimi przedsiębiorcami etnicznymi. Na ich podstawie zidentyfikowaliśmy cztery różne typy wartości kulturowych, które maja decydujqcy wpływ na działalność przedsiębiorców wietnamskich w Niemczech: i) zaangażowanie rodziny, ii) ostrożność w podejmowaniu decyzji biznesowych, iii) asertywność w społeczności i iv) uprzejmość obsługi. Badanie oferuje wstępny wgląd $w$ rolę wartości kulturowych w procesach podejmowania decyzji przedsiębiorczych przez przedsiębiorców etnicznych i uznaje wzajemny wpływ między wartościami kulturowymi a równowagq osadzenia.
\end{abstract}

Słowa kluczowe: wartości kulturowe, przedsiębiorczość etniczna, przedsiębiorcy etniczni, osadzenie, wietnamscy przedsiębiorcy etniczni 


\section{Biographical notes}

Quynh Duong Phuong is a research assistant at the Chair in Small Business \& Entrepreneurship (LEMEX) of the University of Bremen. Her research interests lie primarily in the fields of diaspora entrepreneurship, transnational entrepreneurship and entrepreneurial ecosystems.

Aki Harima is a postdoctoral researcher at the Chair in Small Business \& Entrepreneurship (LEMEX) of the University of Bremen. Her research interests lie in transnational entrepreneurial activities of migrants and refugees, startup ecosystems and entrepreneurial support institutions such as accelerators and incubators. Aki Harima is also one of the main organizers of the International Conference on Migration and Diaspora Entrepreneurship (MDE). She is engaged in international teaching activities and has given seminars and lectures in Pachuca/Mexico (Universidad Autónoma del Estado de Hidalgo), Oxford/ England (EM Normandie), Bloemfontein/South Africa (University of Free State) and Windhoek/Namibia (Namibian University of Science and Technology). 
